\title{
共焦点顕微ラマン分光法を用いた炭素繊維強化複合材料中の 残留応力ならびに内部応力マッピング†
}

\author{
來 海 博 央 ${ }^{*}$ 與 語 勇 - ** \\ 池田竜 也 ${ }^{* * *}$ 水野 良 政****

\begin{abstract}
Mapping Measurement of Residual and Internal Stresses in Carbon Fiber Reinforced Plastics by Confocal Raman Microspectroscopy
\end{abstract}

by

\author{
Hirohisa Kıмаснг ${ }^{*}$, Yuichi Yogo ${ }^{* *}$, Tatsuya IKedA ${ }^{* * *}$ and Yoshimasa Mizuno ${ }^{* * * *}$
}

In this study, residual and internal stresses of PAN-based carbon fiber in CFRP were measured by confocal Raman microspectroscopy with sub-micro scale spatial resolution. For single carbon fiber, the relationships between the change of Raman bad shift and applied stress were obtained by single fiber tensile test. The relationship for Raman band peak at $2691 \mathrm{~cm}^{-1}$ indicated high linearity and high stress resolution. Residual stresses of carbon fiber in CFRP were determined by using the relationship for $2691 \mathrm{~cm}^{-1}$ Raman line. Residual stresses of several carbon fibers in $4 \sim 7 \mu \mathrm{m}$ depth from the specimen surface were measured. Then, residual stresses were compressive and the mean stress was about -625MPa. The mapping measurement of residual stress of carbon fiber in CFRP was conducted. The fibers on the specimen surface had low compressive stress, and fibers in matrix had high compressive stress. Last, the mapping measurement of residual and internal stresses near the crack tip in CFRP under mode I loading was conducted. Change of stress field around the crack tip was observed from differences between residual and internal stress distributions. Therefore, the availability of confocal Raman microspectroscopy to stress evaluations of CFRP was confirmed.

Key words : CFRP, Confocal Raman microspectroscopy, Carbon fiber, Residual stress, Internal stress, Mapping measurement

\section{1 緒言}

炭素繊維強化プラスチックス (CFRP : Carbon Fiber Reinforced Plastics) は, 比強度, 比剛性に優れている ため, 航空機の一次構造部材から, 近年では, 自動車へ の応用も試みられ，CFRP 構造物の高信頼性化が求めら れている.

CFRP の材料特性，破壞じん性や疲労特性等は， CFRP が有するマトリックス, 繊維, さらに繊維/マト リックス界面などのメゾ構造に大きく支配されている. ${ }^{1)}$ さらにメン゙構造に起因して, 製造過程にCFRP を構成す る各相の熱膨張係数差によって生じる残留応力も破壞じ 几性や疲労特性等に影響を与える. ${ }^{2) ~}{ }^{2)}$ 接合材 ${ }^{7)}$ p $\left.\mathrm{CFRP}^{8}\right)$ 中の内部応力はき裂進展径路を支配し, 破壞じん 性やき裂進展特性を左右する要因となるため, CFRP 中 の残留応力や内部応力を評価することは大変重要である.

CFRP の残留応力や内部応力の評価例としては, X 線 回折法 ${ }^{9)}$, 10) を用いた例が報告されている。測定領域が大 きいため平均的な残留応力や内部応力を評価する上では 大変有効な手法であるが, 直径 $5 \mu \mathrm{m}$ 前後の繊維とそれ に相当するマトリックスで構成されている CFRP のメゾ
スケールでの応力場を精度よく測定することは困難であ る。これらに対し, CFRP と同じメゾスケールの応力評 価法として顕微ラマン分光法を用いた例が報告されてい る. ${ }^{11) ~ 199}$ 顕微ラマン分光法はレーザーを用いることで大 気中での非破壞・非接触の応力測定が可能であり, $1 \mu \mathrm{m}$ 程度の高空間分解能を有している。これまでにも, 顕微 ラマン分光法を用いた CFRP 中の応力評価は行われてい るが,15)そのほとんどがモデルコンポジットを対象とした 研究 16) 18) P CFRP にラマン活性剤で被膜处理を行い, 被膜のひずみを測定した研究 ${ }^{19} に$ に限られている。また実 CFRP の場合, 繊維含有率が $40 \sim 60 \%$ となると隣接する 繊維が近くなるため, 通常の顕微ラマン分光法ではレー ザーが通過する領域の散乱光を検出するため, 繊維毎の 応力を評価することは困難となる。さらに，CFRP 中の 残留応力や内部応力のマッピング測定をメゾスケールで 行った例はほとんど無い。

そこで本研究では，サブミクロン空間分解能を有する 共焦点型光学顕微鏡をべースに構築した顕微ラマン分光 法を用いて， CFRP 中の炭素纎維に働く内部応力なら びに残留応力マッピングを行った。ささらに CFRP 中のき

\footnotetext{
† 原稿受理 平成 22 年 8 月 9 日 $\quad$ Received Aug. 9, 2010 C 2011 The Society of Materials Science, Japan

* 正 会員 名城大学理工学部機械システム工学科 テ468-8502 名古屋市天白区塩釜口, Dept. of Mech. Eng., Meijo Univ., Tempaku-ku, Nagoya, 468-8502

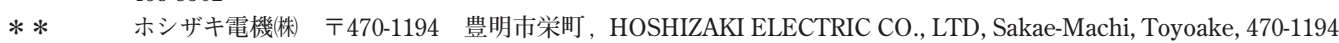

***？アイシン精機(株)干448-8650 刈谷市朝日町, AISHIN SEIKI CO., LTD, Asahi-machi, Kariya, 448-8650

$* * * * \quad$ 京七ラ(株) $\bar{*} 612-8501$ 京都市伏見区竹田鳥羽殿町, KYOCERA. Co., Fushimi-ku, Kyoto, 612-8501
} 
裂先端の残留応力ならびにモードＩ荷重下におけるき裂 先端近傍の作用応力のマッピング測定を行い, CFRP 中 の内部応力の変化を明らかにした.

\section{$2 \cdot 1$ 供試材および試験片}

\section{2 実 験 方 法}

本研究では, PAN 系高弾性タイプ炭素繊維 (東邦テナッ クス(株)製 UM55-12K）を用いた。一方 CFRPは，同炭 素繊維をエポキシ樹脂（\#118）で固めたプリプレグシー ト（東邦テナックス株製 QT-118）を一方向に積層した ものを用いた。各材料特性を Table 1，2 に示す。

Fig. 1 (a)に内部応力測定ならびに残留応力測定に用 いた CFRP 平滑試験片の形状を示す。内部応力測定では， 銅板試験片の表面に同形状のプリプレグシート 1 枚を貼 り，第一昇温度の $80^{\circ} \mathrm{C}$ まで加熱して 30 分保持した後， 第二昇温度の $130^{\circ} \mathrm{C}$ まで加熱して $0.3 \mathrm{MPa}$ の圧力下で 2 時間保持して硬化させた。 その後，大気中で自然冷却さ せた。裏面にはひずみゲージを貼り付けた。以後本試験 片を, CFRP-Cu 平滑試験片と呼ぶ。

残留応力測定には，内部応力測定と同じ Fig. 1 (a)の

Table 1 Mechanical properties of carbon fiber.

\begin{tabular}{l|c}
\hline Carbon fiber & UM55-12K \\
\hline Young's modulus, $E \mathrm{GPa}$ & 540 \\
\hline Tensile strength, $\sigma_{\mathrm{B}} \mathrm{MPa}$ & 3820 \\
\hline Elongation, $\delta \%$ & 0.7 \\
\hline Diameter, $d \mu \mathrm{m}$ & 4.4 \\
\hline Density, $\rho \mathrm{g} / \mathrm{cm}^{3}$ & 1.92 \\
\hline
\end{tabular}

Table 2 Material properties of prepreg sheet.

\begin{tabular}{l|c}
\hline Prepreg sheet & QT-118 \\
\hline Caron fiber & UM55 \\
\hline Epoxy resin & $\# 118$ \\
\hline Volume fraction, $V_{\mathrm{f}} \%$ & 60.5 \\
\hline Sheet thickness, $t_{\mathrm{s}} \mathrm{mm}$ & 0.091 \\
\hline
\end{tabular}
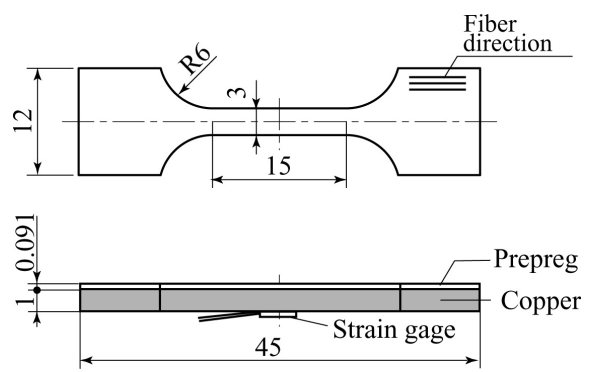

(a) Smooth specimen

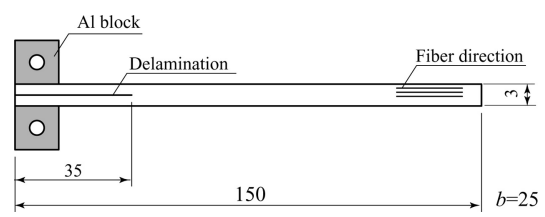

(b) DCB specimen

Fig. 1 Dimensions of FRP smooth specimen and DCB specimen.
試験片形状を用いた。試験片は，プリプレグシートを 6 枚積層させ，同一形状で同一成型条件のもとで作製した。 このとき，試験片厚さは $0.5 \mathrm{~mm}$ であった。以後本試験 片を, CFRP 平滑試験片と呼ぶ.

Fig. 1 (b)に，DCB 試験片を示す。試験片には，同一 のプリプレグシートを用いて積層し，積層中央部にカプ トンフィルムを挿入することで，人工的なはく離き裂を 導入した。試験には負荷用アルミブロックを試験片に貼 付けて使用した。

\section{$2 \cdot 2$ 実験装置}

共焦点顕微ラマン分光装置の構成を Fig. 2 に示す。装 置は, 共焦点型光学顕微鏡, 冷却 CCD 検出器, イメー ジング分光器, レーザー出力装置, 制御用コンピュータ, ピエゾステージで構成され，分光計はシングルモノクロ メーターである.レーザーは固体レーザー (DPSS レーザー) で中心波長 $488 \mathrm{~nm}$ ，対物レンズに 100 倍レンズ (オリンパ ス(株)製 NA比 = 0.95）を用いることで照射領域は約 $700 \mathrm{~nm}$ となっている。また共焦点ピンホールにより $250 \mathrm{~nm}$ の空間分解能を有しており，深さ方向にもサブミ クロン空間分解能が確保されている。測定值は深さ方向 を含めた 3 次元領域の平均值となる. 本装置でのレーザー 入射，検出では，入射側に偏光板と回転制御が可能な $\lambda / 2$ 板，検出側に回転制御が可能な偏光板を有している. 測定では， $\lambda / 2$ 板を回転させ，繊維方向とレーザーの振 動方向を合わせることで，短時間で高強度のラマンスぺ クトルを測定した。ステージは粗動ステージと精密ピエ ゾステージを備え，精密ステージは $x y$ 方向に $100 \mu \mathrm{m} \times$ $100 \mu \mathrm{m}$ で，最小移動分解能は $1.0 \mathrm{~nm}$ である。また対物 レンズ用ピエゾステージを備え，最大移動範囲は $30 \mu \mathrm{m}$, 最小移動分解能が $1.0 \mathrm{~nm}$ で, 焦点位置をナノオーダーで 調整して測定した

\section{$2 \cdot 3$ 炭素繊維単体の引張試験}

$2 \cdot 3 \cdot 1$ 単繊維引張試験機 使用した炭素繊維単体 の引張試験機を Fig. 3 に示す。試験機は，炭素繊維の配 置の微調整が可能なように,$y$ 方向の位置調整用電動ス テージ (中央精機株)製 ALS-602-HOM)， $z$ 方向の位置調 整用ステージ (中央精機(株)製 LV-931-2) で構成され， 荷重はクロスヘッド用電動ステージ（中央精機(株)製 ALS602-HOM）を $x$ 方向に微小変位させることで付与した. 荷重の検出には微小荷重用ロードセル (株)共和電業製 LTS-50GA，荷重分解能 $0.1 \mu \mathrm{N} ）$ を用いた。

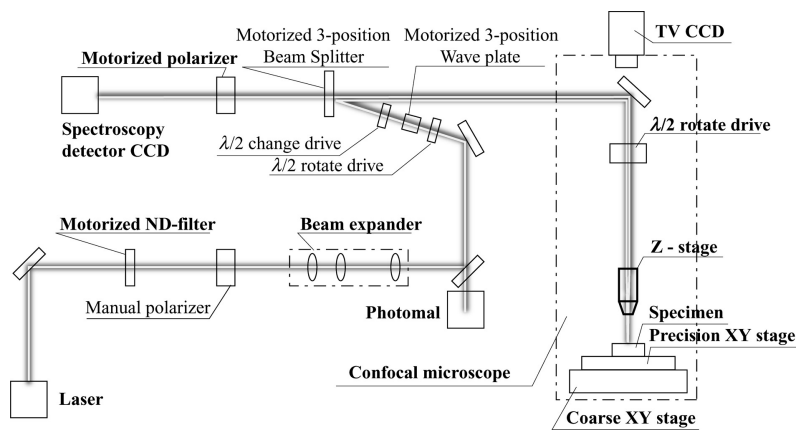

Fig. 2 System of confocal Raman microspectroscope. 


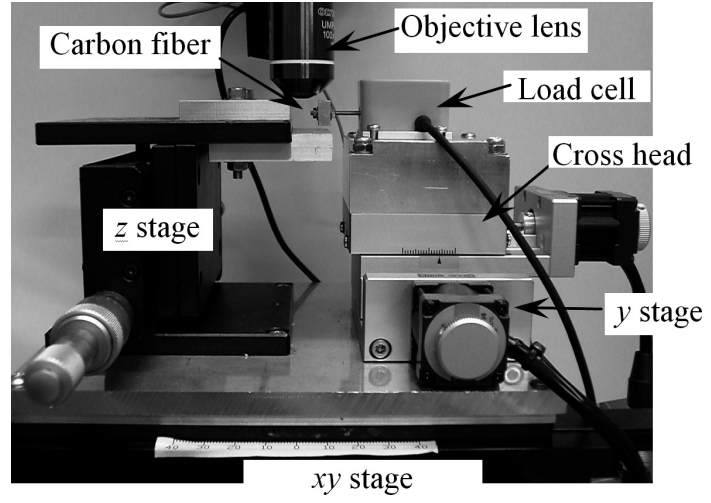

Fig. 3 Single carbon fiber testing machine.

2・3・2 試験方法 Fig. 4 に示すような炭素繊維 1 本の両端をプラスチック片に接着剤で固定した炭素繊維 試験片を, 水平配置された単繊維引張試験機のチャッキ ング治具に固定した後，炭素繊維が対物レンズ直下とな る様に位置調整をした。レーザーの焦点を炭素繊維に合 わせ，レーザーを照射した状態で，クロスヘッド（ $x$ ス テージ）をステップさせることで荷重を付与した。 各荷 重でラマンスペクトルを測定し, 炭素纎維単体の負荷応 カとラマンスペクトルのシフト量の関係を算出した。 ク ロスヘッドの送りは $5 \mu \mathrm{m}$ とし, 測定条件はレーザー強度 $1.2 \mathrm{~mW}$ で照射時間 $20 \mathrm{~s}$ とした。

\section{$2 \cdot 4$ CFRP の内部応力評価}

銅板にプリプレグシートを 1 枚接着した CFRP-Cu 平 滑試験片を自作の小型引張試験機 (Fig. 5) に取り付けた 後, 引張負荷を段階的に付与し, 顕微ラマン分光法を用 いて内部応力の測定を行った。本試験により, ラマンス ペクトルから得られる CFRP 中の炭素繊維の応力を検証 した。測定条件は，レーザー強度 $1.2 \mathrm{~mW}, 1$ 回の測定に おける照射時間 20 s とした。

\section{2・5 CFRP の残留応力評価}

CFRP は, 加熱・加圧して成型するため, 炭素繊維と

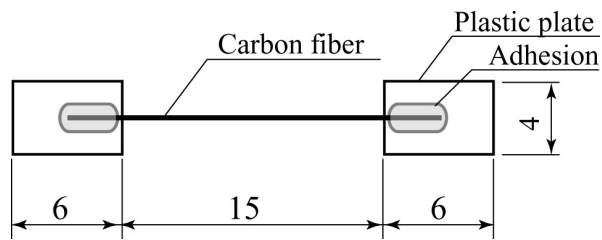

Fig. 4 Single carbon fiber specimen.

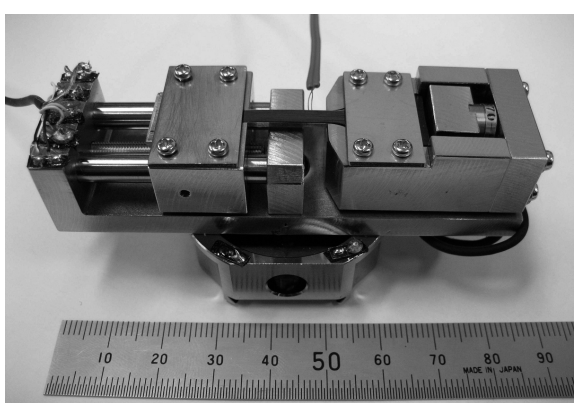

Fig. 5 Small tensile test machine.
エポキシ樹脂の熱膨張係数の違いにより残留応力が発生 する，そこで，炭素纎維のラマンピークシフトの変化量 から，CFRP 中の炭素繊維に働く残留応力を測定した。 測定には CFRP 平滑材を用い, 試験片中の炭素繊維のう ち, 表面から $4 \sim 7 \mu \mathrm{m}$ 程度埋没している繊維について測 定を行った。

さらに同試験片の $40 \mu \mathrm{m} \times 40 \mu \mathrm{m}$ の正方形領域におけ る残留応力のマッピング測定を行った。試験片表面は， \#2000 の耐水研磨紙を用いて研磨後，0.3um のアルミナ 㲘濁液を用いてバフ研磨で仕上げた。測定条件は，レー ザー強度 $1.2 \mathrm{~mW}, 1$ 回の測定における照射時間 $20 \mathrm{~s}$ とし, マッピング測定は測定間隔を $4 \mu \mathrm{m}$ とした。

\section{$2 \cdot 6$ CFRP 中のき裂先端近傍の内部応力評価}

DCB 試験によりモード I 荷重を負荷し，CFRP 中のき 裂先端近傍の炭素瀻維の応力評価を行った。荷重は変位 制御により付与した。試験は，ラマン分光装置のステー ジ上に設置できる小型の DCB 試験装置を製作して行っ た。荷重検出には，500N のロードセル（ユニパルス㑣 製 UNCDW-500N）を用いた。マッピング測定領域は, き裂を挟んだ上下の $20 \mu \mathrm{m} \times 25 \mu \mathrm{m}$ 領域とした．測定条 件は，レーザー強度 $2 \mathrm{~mW} ， 1$ 回の測定における照射時間 20sとした。

\section{3 実 験 結 果}

\section{$3 \cdot 1$ 炭素纎維単体の負荷応カとラマンシフトの関係} 本研究で使用した炭素繊維の無負荷状態に打けるラマ ンスペクトルを Fig. 6 に示す. ラマンスペクトルは材料 固有の波形を示し， $1335 \mathrm{~cm}^{-1}, 1557 \mathrm{~cm}^{-1}, 2424 \mathrm{~cm}^{-1}$, $2691 \mathrm{~cm}^{-1}, 2927 \mathrm{~cm}^{-1}, 3218 \mathrm{~cm}^{-1}$ に打いて明確なピーク が現れた。始めの 2 つのピークは炭素瀻維の一次振動 モードで, 残り 4 つのピークは二次振動モードである.20) 特に $1335 \mathrm{~cm}^{-1}$ は非結晶性炭素に起因する $\mathrm{D}$ バンド $\left(\mathrm{A}_{1 \mathrm{~g}}\right.$ 振動モード), $1557 \mathrm{~cm}^{-1}$ はグラファイトの面内振動に起 因する $\mathrm{G}$ バンド $\left(\mathrm{E}_{2 \mathrm{~g}}\right.$ 振動モード）が強く現れた. ${ }^{21)}$ この $\mathrm{G}$ バンドに対する $\mathrm{D}$ バンドピークの強度比 $I_{\mathrm{D}} / I_{\mathrm{G}}$ は炭素 繊維の結晶性評価に用いられるが，本材料の場合， Gバ ンドピークである $1557 \mathrm{~cm}^{-1}$ のピーク強度が高く，その比 も 0.408 と結晶性の高い繊維であった。さらに $\mathrm{A}_{1 \mathrm{~g}}$ 振動 モード $\left(1337 \mathrm{~cm}^{-1}\right)$ の二次振動モードである $2691 \mathrm{~cm}^{-1}$ 付

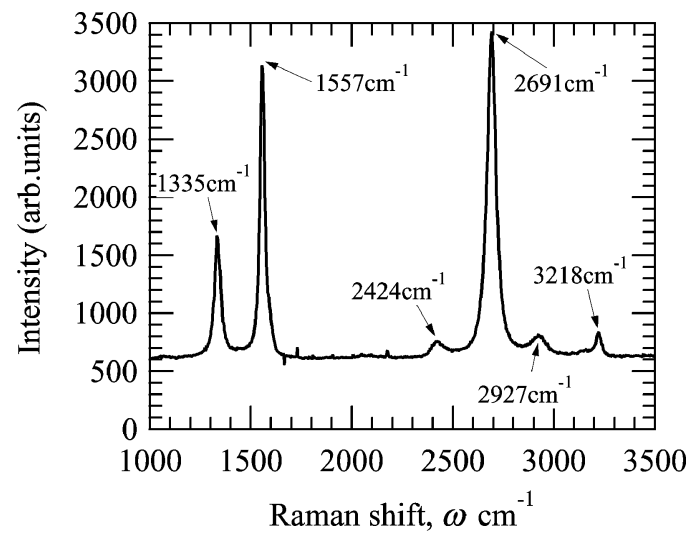

Fig. 6 Raman spectrum of single carbon fiber. 


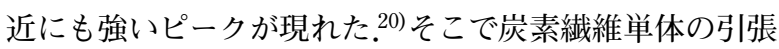
試験を行い，3つのピークについて負荷応力に対するラ マンスペクトルの変化を測定した. Fig. 7 に, 繊維単体 に打ける負荷応力とラマンピークシフトの変化量の関係 を示す．横軸は負荷応力 $\sigma_{\mathrm{a}} \mathrm{GPa}$, 縦軸はラマンピークシ フトの変化量 $\Delta \omega \mathrm{cm}^{-1}$ である. $1335 \mathrm{~cm}^{-1}, 1557 \mathrm{~cm}^{-1}$, $2691 \mathrm{~cm}^{-1}$ の各ピークにおける負荷応力とラマンピークシ フトの変化量の関係には高い線形性が得られた. 各ピー クに対する関係は次式となった。

$$
\begin{aligned}
& \Delta \omega_{1335}=-1.7099 \sigma_{a} \\
& \Delta \omega_{1557}=-2.2621 \sigma_{a} \\
& \Delta \omega_{2691}=-4.8328 \sigma_{a}
\end{aligned}
$$

二次振動モードである $2691 \mathrm{~cm}^{-1}$ が最も応力分解能が高 く，線形性も高くなった。これは Gliotis らによる報告 ${ }^{22)}$ と同じ傾向が得られた。そこで本研究では，2691 $\mathrm{cm}^{-1}$ 付 近のピークを用いて炭素繊維に作用する応力を算出した。 また CFRP 中の応力評価には，引張側だけではなく圧縮 側に対してもラマンシフトの変化量を表す式が必要とな るが, 結晶性が高い場合，両者はほぼ等しいことが報告 されている. ${ }^{23)}$ 本研究で用いた炭素繊維の場合, 報告例 ${ }^{23)}$ よりも結晶性が高い $\left(I_{\mathrm{D}} / I_{\mathrm{G}}=0.408\right)$ ことから, 圧縮側の 関係式は引張側と同じとした。

\section{$3 \cdot 2$ CFRP の引張試験による内部応力の評価}

成型した CFRP-Cu 平滑試験片の炭素繊維のラマンス ペクトルのうち, $2691 \mathrm{~cm}^{-1}$ 付近の波形を Fig. 8 に示す. エポキシ樹脂に埋没している炭素繊維のラマンスペクト ルには, $2800 \sim 3200 \mathrm{~cm}^{-1}$ 付近にエポキシ樹脂のラマン スペクトルが重複して現れる。そこで，スペクトルの波 形フィッティングを行い, 各ピークを分離することで, 炭素繊維のラマンスペクトルのピークシフトを精度よく 求め, CFRP 中の炭素繊維に働く応力を算出した.

次に $\mathrm{CFRP}-\mathrm{Cu}$ 平滑試験片に引張負荷を与え, 炭素繊 維のラマンスペクトルから CFRP 中の炭素繊維の内部応 力を評価した。その結果を Fig. 9 に示す。縦軸には，ラ マンスペクトルから得られた応力の変化量 $\Delta \sigma_{\mathrm{a}, \mathrm{R}}$ をと た。横軸には銅試験片側に張付けられたひずみゲージか ら試験片に作用しているひずみを求め，このひずみ量と 炭素繊維のヤング率から算出した応力の変化量 $\Delta \sigma_{\mathrm{a}, \mathrm{S}}$ を

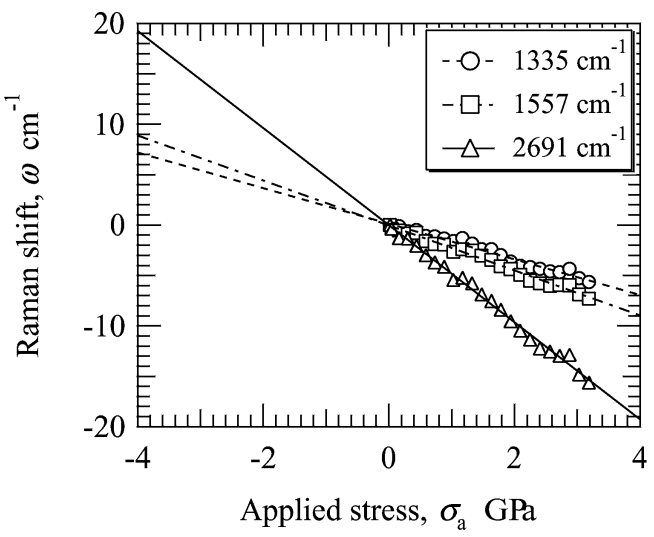

Fig. 7 Relationship between Raman shift and applied stress for single carbon fiber.

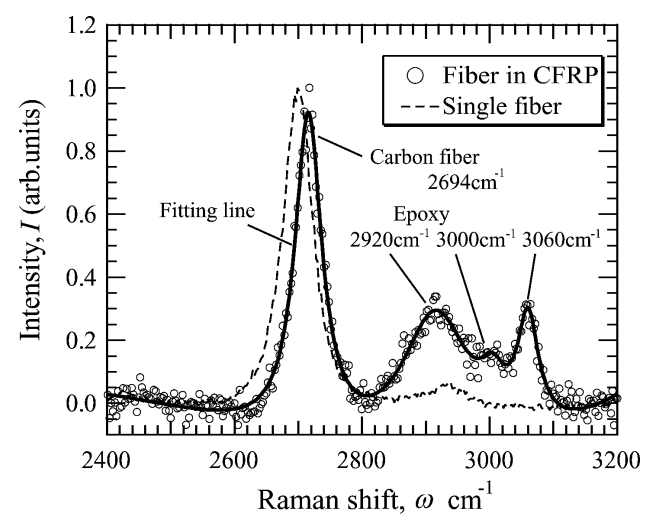

Fig. 8 Raman spectrum of carbon fiber in CFRP.

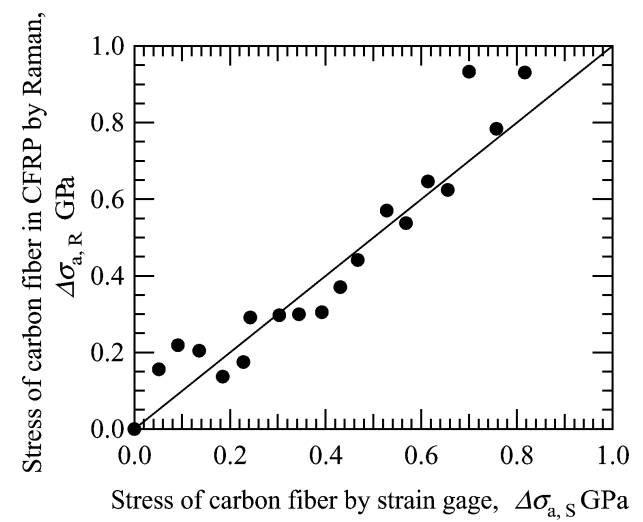

Fig. 9 Comparison of stress between by Raman Shift and by strain gage.

とった．銅試験片に接着されたプリプレグシートは約 $90 \mu \mathrm{m}$ と銅試験片に対して非常に薄いため，プリプレグ シート内のひずみは銅試験片とほぼ同一と考えられる。

顕微ラマン分光法による応力 $\Delta \sigma_{\mathrm{a}, \mathrm{R}}$ とひずみゲージに よる応力 $\Delta \sigma_{\mathrm{a}, \mathrm{S}}$ の間に傾き 1 の関係が得られている．以 上により, CFRP 中の炭素繊維の応力の変化を精度よく 測定できることが分かる.

\section{$3 \cdot 3$ CFRP 中の局所残留応力測定}

CFRP 内部の残留応力を測定するため, $\mathbf{3} \cdot \mathbf{2}$ 節と同様 な波形分離を行い, $2691 \mathrm{~cm}^{-1}$ 付近における炭素繊維のラ マンピークシフトの変化量を精度よく求めた．測定した CFRP 表面の顕微鏡写真を Fig. 10 に示す. 図中の A $\mathrm{F}$ の測定点は，すべてエポキシ樹脂に $4 \sim 7 \mu \mathrm{m}$ 埋没して いる炭素繊維である．残留応力と繊維の埋没深さの測定 結果をまとめて Table 3 に示す. 各測定点において圧縮 の残留応力を示し，その平均值は約- $625 \mathrm{MPa}$ となった。

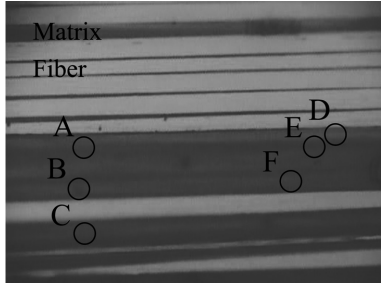

(a) Specimen surface

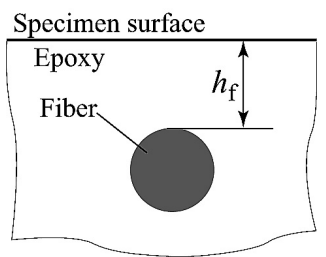

(b) Cross section
Fig. 10 Measurement points of residual stress in CFRP 
Table 3 Residual stresses of carbon fiber in CFRP.

\begin{tabular}{c|c|c}
\hline Point & $\begin{array}{c}\text { Depth from the } \\
\text { surface, } h_{\mathrm{f}} \mu \mathrm{m}\end{array}$ & $\begin{array}{c}\text { Residual stress, } \\
\sigma_{\mathrm{R}} \mathrm{MPa}\end{array}$ \\
\hline A & 7 & -720.2 \\
\hline B & 5 & -826.2 \\
\hline C & 4 & -722.7 \\
\hline D & 4 & -458.6 \\
\hline E & 7 & -414.0 \\
\hline F & 7 & -606.8
\end{tabular}

本研究では共焦点型光学顕微鏡を使用しているため, 従 来とは異なり，焦点領域の情報のみを抽出することがで き，表面に無い，埋没深さが異なる繊維を区別して応力 を測定することができる.

次に, CFRP 中の $40 \mu \mathrm{m} \times 40 \mu \mathrm{m}$ 領域における残留応 力のマッピング測定の結果を Fig. 11 に示す．測定した 試験片表面の顕微鏡画像を (a)に示す。表面に現れてい る炭素繊維では低い圧縮残留応力となり応力が解放され ていた. 一方, エポキシ内部の炭素繊維（深さ $4 \sim 7 \mu \mathrm{m}$ ) では高い圧縮残留応力が測定された，従って，共焦点型 光学顕微鏡を用いることで，埋没深さが異なり繊維が密 に存在する領域についても，残留応力のマッピング測定 ができることが分かる.

\section{$3 \cdot 4$ CFRP 中のき裂先端近傍の炭素繊維の応力測定}

Fig. 12 にCFRP 中のき裂先端近傍の上下の $20 \mu \mathrm{m} \times$ $25 \mu \mathrm{m}$ 領域の炭素繊維の応力のマッピング測定の結果を 示す. (a)がき裂先端周辺の測定領域の顕微鏡画像である. 測定領域は，カプトンフィルムからある程度き裂進展させ た位置とした．無負荷状態で測定した (b) の残留応力分布 では，表面に出ている繊維の内，上側の繊維番号 $1 \sim 6$ で $100 \sim 200 \mathrm{MPa}$ 程度，下側の繊維 $1 \sim 3$ で 0 〜 $100 \mathrm{MPa}$ 程度の引張残留応力が測定された。一方，下側 の領域にある埋没した炭素繊維 $(\# 4 ＼mathrm{~ ） ~ に つ い て は ~} 0$ 〜
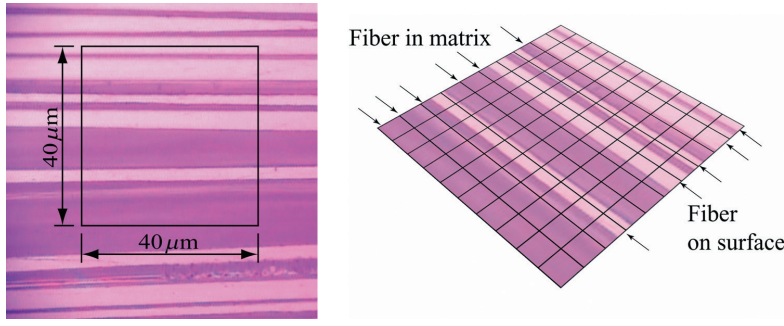

(a) Optical micrograph of mapping area on CFRP surface

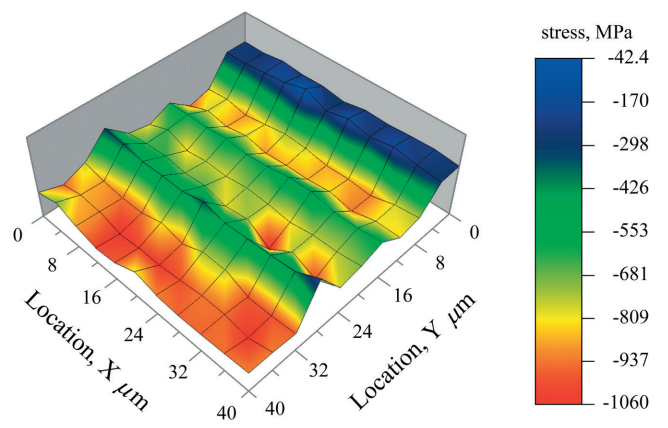

(b) Distribution of residual stress in fiber direction

Fig. 11 Mapping measurement of residual stress of fiber in CFRP.

$100 \mathrm{MPa}$ 程度の圧縮残留応力が測定された。これは，き 裂進展後に除荷して応力を測定したため，き裂先端周辺 の樹脂が塑性変形し , $3 \cdot 3$ 節で測定されたレベルの表面 と内部の繊維の圧縮応力がそれぞれ引張側にシフトした ものと考えられる。 これに対して，破壊じん性值の $60 \%$ $\left(K_{\mathrm{Ia}}=0.6672 \mathrm{MPa} \sqrt{\mathrm{m}}\right.$, 破壊じん性值 $\left.K_{\mathrm{Ic}}=1.112 \mathrm{MPa} \sqrt{\mathrm{m}}\right)$ まで負荷した (c) の場合, 測定領域の上側では完全に引 張応力に変化し，下側のすべての繊維についても，き裂 前方の領域では圧縮側から引張側へと変化している様子 が伺える。一方，き裂先端内側の繊維（下側の\#5）では 一部圧縮応力が観察された。 (d) は, 無負荷状態の応力 分布 (b) から荷重負荷後の応力分布 (c) までの応力の変

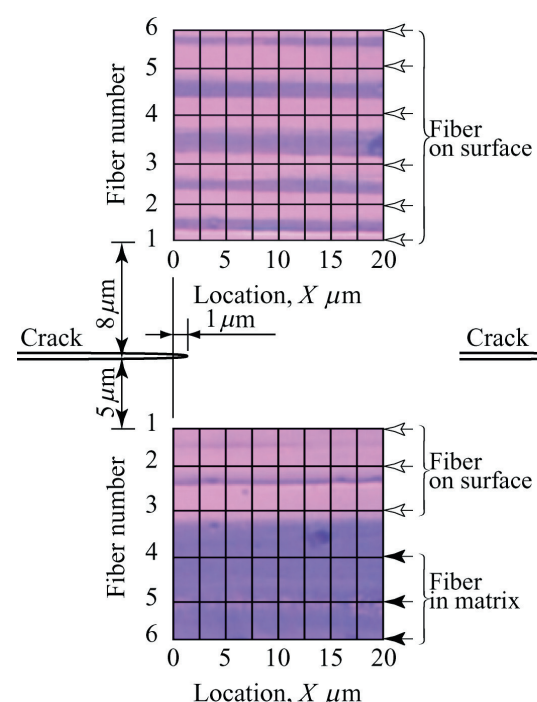

(a) Mapping area
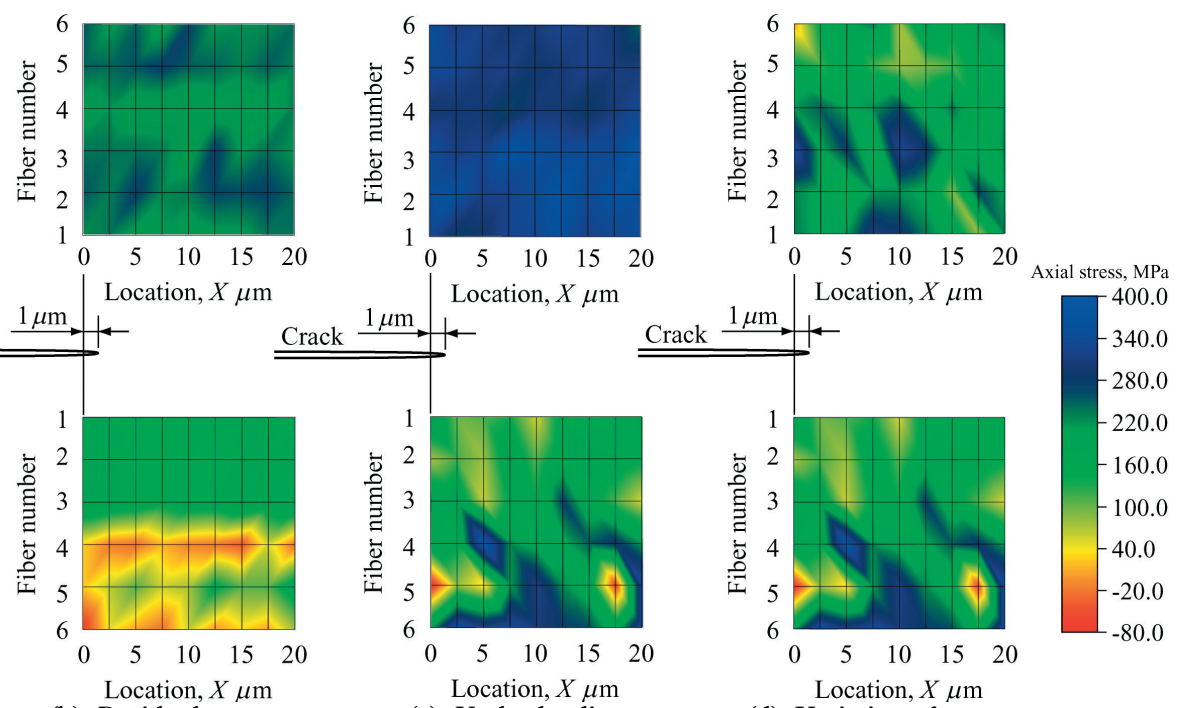

Location, $X \mu \mathrm{m}$

(b) Residual stress
Location, $X \mu \mathrm{m}$

(c) Under loading (d) Variation of stress

Fig. 12 Stress mapping of fiber around crack tip in CFRP. 
化量を示している．き裂先端付近の炭素繊維（上側の繊 維 \#1,\#3）の応力の増加量が大きく, 遠方では小さくなっ た。一方き裂面下方の樹脂に埋没した繊維（下側の繊維 \#4 ～6）の応力の増加は大きい結果となった. 以上より, 顕微ラマン分光法によってモードＩ荷重下でのき裂先端 近傍の応力場の広がりを捉えることができており，共焦 点型光学顕微鏡で構築された顕微ラマン分光法を用いる ことで，CFRP 中のき裂近傍の応力を測定できることが 分かる。また，CFRPの信頼性評価においては有用な測 定法であることが分かる。しかしながら，今後より内部 の応力を高精度に捉えるためには，本研究で使用した波 長 488nm 以上に波長を長くして進入深さを大きくするな ど, 今後さらなる検討が必要である。

\section{4 結} 言

本研究では，顕微ラマン分光法による実 CFRP 中の局 所応力測定を行うため, 応力測定に必要な負荷応力とラ マンスペクトルの変化量の関係を算出し, 残留応力測定, き裂先端近傍の応力場のマッピング測定を行った。得ら れた主な結果を以下に示す。

(1) 応力への換算に必要な炭素繊維単体の負荷応力と ラマンシフトの関係は，1335 $\mathrm{cm}^{-1}, 1557 \mathrm{~cm}^{-1}, 2691 \mathrm{~cm}^{-1}$ 付近のピークにおいて線形性が得られ，中でも $2691 \mathrm{~cm}^{-1}$ のラマンシフトは特に高い線形性と高い応力分解能が得 られた。

(2) CFRP 中の局所残留応力測定を, 試験片表面に無 い，深さの異なる複数の繊維について行った，共焦点型 光学顕微鏡を用いることで，従来困難であった深さの異 なる繊維の残留応力を評価することができた，測定され た点での平均值は，打よそ $625 \mathrm{MPa}$ の圧縮応力となった。

(3) CFRP の残留応力のマッピング測定では，試験片 表面に現れている炭素繊維では低い圧縮残留応力が, CFRP 中の炭素繊維では高い圧縮残留応力が測定された. 共焦点型光学顕微鏡を用いることで，深さの異なる繊維 だけでは無く, レーザー光路に近い隣接した繊維の残留 応力を区別して評価することができた.

(4) DCB 試験片のき裂先端近傍の応力場を評価し, 負荷前の残留応力，負荷後の作用応力を評価し，き裂先 端からの応力場の変化を捉えることができた。

最後に，本研究で使用した炭素繊維ならびにプリプレ グシートは東邦テナックス(株より拝受した。また本研究 を遂行するにあたり，当時大学院生の森 洋介君（現， ヤマザキマザック(株)），山本真司君（現，デンソー(株)）に ご協力いただいた，関係各位に，ここに記して感謝の意 を表する。

\section{参 考 文 献}

1) K. Friedrich, "Fractographic analysis of polymer composites", Composite Material Series 6, Application of Fracture Mechanics to Composite Materials, pp.425-487 (1989) Elsevier Science.

2 ) J. A. Nairn, "Fracture mechanics of composites with residual thermal stresses”, Journal of Applied Mechanics, Vol.64, pp.804-815 (1997).
3 ) J. A. Nairn, "Fracture mechanics of composites with residual stresses, imperfect interfaces, and tractionloaded cracks", Composites Science and Technology, Vol.61, Issue 15, pp.2159-2167 (2001)

4 ) B. Fiedler, M. Hojo and S. Ochiai, "The influence of thermal residual stresses on the transverse strength of CFRP using FEM", Composites Part A : Applied Science and Manufacturing, Vol.33, Issue 10, pp.1323-1326 (2002).

5 ) M. de Freitas and R. de Carvalho, "Residual strength of a damaged laminated CFRP under compressive fatigue stresses”, Composites Science And Technology, Vol.66, pp.373-378 (2006).

6) M. Arai, T. Sumida and M. Shimizu, "Effect of residual stress on interlaminar fracture toughness of CFRP laminates”, Journal of Thermal Stresses, Vol.30, Issue 11, pp.1099-1116 (2007).

7 ) N. A. Fleck, J. W. Hutchinson and Z. Suo, "Crack path selection in a brittle adhesive layer", International Journal of Solids and Structures, Vol.27, No.13, pp.1683-1703 (1991).

$8)$ H. Kimachi, H. Tanaka, K. Tanaka and K. Yoshida, "Propagation path of interlaminar cracks in continuous fiber-reinforced plastics under remote mode I loading", Transactions of the Japan Society of Mechanical Engineers. Series A, Vol.66, No.646, pp.1143-1150 (2000)

9 ) C. Balasingh and V. Singh, "Measurement of residual stresses in CFRP laminates by X-ray diffraction method", Bulletin of Materials Science, Vol.20, No.3, pp.325-332 (1997).

10) B. Benedikt and M. Kumosa, "An analysis of residual therma stresses in a unidirectional graphite/PMR-15 composite based on X-ray diffraction measurements”, Composites Science and Technology, Vol.61, Issue 14, pp.1995-2006 (2001).

11) V. T. Srikar, A. K. Swan, M. S. Ünlü, B. B. Goldberg and S. M. Spearing, "Micro-Raman measurement of bending stresses in micromachined silicon flexures”, Journal of Microelectromechanical System, Vol.12, Issue 6, pp.779-787 (2003).

12) S. J. Harris, A. E. O’ Neill, W. Yang, P. Gustafson, J. Boileau, W. H. Weber, B. Majumdar and S. Ghosh, "Measurement of the state of stress in silicon with micro-Raman spectroscopy", Journal of Applied Physics, Vol.96, Issue 12, pp.7195-7201 (2004).

13) H. Kimachi, S. Yamamoto, W. Ota, K. Shirakihara and Y. Fujita, "Measurement of local stress components in single crystal alumina by using Raman microspectroscopy with sub-micro spatial resolution", Journal of the Society of Materials Science, Japan, Vol.58, No.7, pp.603-609 (2009).

14) H. Kimachi, W. Ota, K. Fujiyama, S. Yamamoto, K. Niwa and D. Kaneko, "Evaluation of thermal damage of thermal barrier coatings by using Raman microspectroscopy”, Journal of The Society of Materials Science, Japan, Vol.59, No.6, pp.455-461 (2010). 
15) Ph. Colomban, G. Gouadec, J. Mathez, J. Tschiember and P. Pérès, "Raman stress measurement in opaque industrial Cf/epoxy composites submitted to tensile strain", Composites : Part A, Vol.37, Issue 4, pp.646-651 (2006).

16) L. S. Schadler and C. Galiotis, "Fundamentals and applications of micro Raman spectroscopy to strain measurements in fibre reinforced composites”, International Materials Reviews, Vol.40, No.3, pp.116-134 (1995)

17) D. Lévêque and M.-H. Auvray, "Study of carbon-fibre strain in model composites by Raman spectroscopy", Composites Science and Technology, Vol.56, Issue 7, pp.749754 (1996).

18) T. Miyake, N. Ohno, M. Mizuno and Y. Yamakawa, "Evaluation of stress relaxation in a broken fiber for a single carbon fiber/epoxy composite by Raman spectroscopy”, Transactions of the Japan Society of Mechanical Engineers. Series A, Vol.64, No.620, pp.981-987 (1998).

19) H. Miyagawa, C. Sato and K. Ikegami, "Evaluation of mesoscopic fracture toughness based on strain measurement in epoxy resin phase near crack tip of CFRP using Raman spectroscopy", Transactions of the Japan Society of Mechanical Engineers. Series A, Vol.68, No.672, pp.12061211 (2002).

20) R. J. Nemanich and S. A. Solin, "First- and second-order Raman scattering from finite-size crystals of graphite", Physical Review B, Vol.20, No.2, pp.392-401 (1979).

21) F. Tuinstra and J. L. Koenig, "Raman spectrum of graphite", Journal of Chemical Physics, Vol.53, Issue 3, pp.1126-1130 (1970).

22) C. Galiotis and D. N. Batchelder, "Strain dependences of the first- and second-order Raman spectra of carbon fibres”, Journal of Materials Science Letters, Vol.7, pp.545-547 (1988).

23) N. Melanitis and C. Galiotis, "Compressional behaviour of carbon fibres, Part 1 A Raman spectroscopic study”, Journal of Materials Science, Vol.25, pp.5081-5090 (1990). 